\title{
THE CONTRIBUTION OF SME DEVELOPMENT ORGANIZATION ON EXPORT: REGIONAL EXAMPLE
}

UDC 334.012.63/.64:339.564

\begin{abstract}
Selim Corekcioglu
Szent István University, Doctoral School of Management and Business Administration, Gödöllö, Hungary

Abstract. In this study, the effects of KOSGEB subsidies on the foreign trade of SMEs were examined and the actions necessary to be taken by KOSGEB (SME Development Organization in Turkey) were emphasized. In the study, T test, ANOVA test and TUKEY tests were used and the study was conducted in Gaziantep, which is the 6th biggest city in Turkey. According to the results, companies' problems are accessing markets, financial problems, qualified personnel, language, and high personnel, raw material and production costs. Carrying out activities by KOSGEB such as market research, finding customers, providing financial support, contribution to qualified personnel salary, encouraging and supporting $R \& D$ activities, and providing consultancy are very important to solve the problems.
\end{abstract}

Key words: Grant, Trade, Export, SME

JEL Classification: F 40, F61, H81

\section{INTRODUCTION}

In recent years, many studies were carried out on the development and facilitating of international trade. Export companies are in a more productive position than companies operating only in the domestic market ( $\mathrm{Hu} \& \mathrm{Tan}, 2016)$. Export firms face additional costs, such as market research, adjustment of products to regulations or shipping costs, among other costs. These additional costs are a reason for more efficient firms to choose international markets.

Received February 22, 2021 / Revised May 10, 2021 / Accepted May 26, 2021

Corresponding author: Selim Corekcioglu

Doctoral School of Management and Business Administration, Szent István University, Páter Károly u. 1, 2100, Gödöllö, Hungary

E-mail: selim3977@hotmail.com 
In addition, exporting firms tend to pay higher wages to their employees than nonexporting firms in the market (Fryges \& Wagner, 2010). It is essential for exporters to gain productivity advantage before they start exporting. Exporters can export not just because they export but because they are efficient, that is, because they are more productive. When considered on an enterprise basis, although an SME's place in the economy is on a micro scale, these micro scales combine to contribute to the economy on a macro scale. For this reason, exporting firms with high productivity will grow faster when costs are reduced, whereas firms with low productivity and non-exporters will not be the same (Bernard et al., 2007).

An economic stabilization program implemented in 1980, the free trade liberalization and market-oriented economic, started reforms in Turkey. In this program, export subsidies and export-oriented growth policies were applied instead of import subsidy policies. Since then, integration into global markets and export orientation became new policy of Turkey. In a few years, these policies had positive effects on Turkish exports (Cinar \& Koc, 2017).

Traditional international trade theories state that the exported products, and accordingly sectors, have a comparative advantage compared to the sectors of other countries, while they state that the imported products, accordingly sectors, have a comparative disadvantage compared to the sectors of other countries (Gnizy et al., 2017).

Companies operating in Turkey must be supported by the state in order to have an advantageous position in the foreign market. Public institutions play an important role during that time. Companies that export or have the potential should be supported not only financially but also with consultancy and coaching services (Astarlioglu, 2017).

Beside these, foreign trade has much importance for companies. These are things like increased revenue, competitive environment, longer product lifecycle, better risk management, exchange rate utilization, access to export finance.

Following the introduction, literature review, which includes former papers related to topic, has been investigated. In the third section, brief information about KOSGEB supports was given. The fourth section contains several discussions: the reason why this analysis was conducted, what is the importance of the paper. After this section, the analyzing techniques for data were given. In the sixth section, data collected from companies analyzed in SPSS software and test result were demonstrated. In the last section, by considering all information such as literature review and test results, suggestions are presented for both policy makers and researchers.

\section{LITERATURE REVIEW}

(Coase, 1960) made a number of assumptions about the government's market interventions. He stated that market interventions should be limited and that the regulation of the market can be done by the market itself. It was argued that the government should only intervene in the market to ensure low transaction costs. Depending on the government, political influences should not be allowed to be involved in the regulatory process.

(Stigler, 1971) examined the effect of the regulation on "cost / benefit" and "supply / demand" in the related to the sector. Putting it all into account, the entry limit is one of the most fundamental pieces that regulatory agencies can do for industry from political interests, according to Stigler. Political decisions sometimes do not reflect the position of majority voters, although political decisions have to maximize the votes of politicians' 
subjects to the constraints of the total economic rents to be redistributed. It talks about the cost of information, training, and most importantly organizational costs for the group and the use of regulation in general. Stigler thinks of political parties as natural monopolies that make regulatory decisions. Stigler's analysis emphasizes that masses of relative group size have an influence on such arrangements, so these decisions are sometimes ineffective (Huberman \& Kahn, 1988).

The political authority creates a natural monopoly on both decision and regulation processes. Competition for getting the benefits from regulation must increase total welfare for the whole society. Regulation needs for market must be analyzed in detail, meet the requirements of the industry and the benefits of the consumer (Deardorff, 1995).

International trade is considered one of the most important factors of economic development and global integration. It is thought that international trade has a positive effect on countries in many ways. Countries experiencing trade liberalization face different aspects and consequences of bilateral trade and international trade. The relationship between trade and income levels and convergence between countries were discussed in a way that takes into account total factor productivity, technological differences and factor accumulation. David Ricardo's dynamic two models of good production proved that trade benefits another group within the country at the cost of diminishing the utility of some groups, taking into account the country's prosperity and growth, and ultimately increased the overall welfare level (Zhang \& Song, 2001).

Another view on the effects of trade on growth and economic welfare implies that, because of the size and economic power of some countries, they can act like a monopoly in the market, so policies are very important in this direction (Rourke, 2001). It is also stated that the role of economic integration through trade history had different effects on the New World as it became more unequal compared to the Old World at the end of the 19th century. Trade policies, complemented by the redistribution elements are significantly important to create an economically and socially sustainable environment at both national and global levels (Alesina \& Rodrik, 1994). Venables, for example, showed that regional inequality in developing countries depends on the natural advantages of some regions over others (Evenett \& Venables, 2002). The Venables model showed that companies investing in big cities due to "increased returns to scale" cause urban structures to deteriorate and make markets inadequate due to the growth of these cities above the optimal. Therefore, he states that this situation leads the economy to export. In fact, this argument contradicts Krugman's argument, indicating that the nature of the geographical environment can be modified to some extent by external factors (Krugman, 1999).

Developing a simple economic geography model (Krugman, 1991) showed that a country can become an industrialized "core" or agricultural "environment". By taking into the consideration approach of (Anderson, 1979) very similar to the gravity model, Krugman argued that firms often tend to locate production facilities closer to geographies with greater demands to utilize economies of scale, minimizing transportation costs. He concluded that the emergence of a differentiation between core and periphery depends on transportation costs, economies of scale, and the share of production in national income. In a more recent study, Krugman makes two conflicting views on geography. While the first view deals with the static role of these features due to the nature of geographical features, the second one considers that similar locations may result in different economic roles depending on factors such as factor inactivity and land rents, depending on the relationship between similar regions. So, it was stated that it can result in two different 
efficiency levels with different economic organizations. As a result, although geography was a destiny affecting the economy in the past, it has started to cease to be a destiny today.

(Bergstrand, 1985) 's empirical tests supported the assumption that goods produced domestically are not perfect substitutes and imported products are a stronger substitute for local goods.

Grossman and Helpman, who work on the trade policies that the government can follow directly by transferring money to a group, can be mentioned. This series of research has opened up the role of the political and institutional environment in determining trade policy (Grossman \& Helpman, 1994).

(Girma et al., 2020) analyzed whether manufacturing grant has effect on Chinese companies' export. At the beginning, they used an analyzing method that takes into account both direct and indirect impact of the government support on export. The findings showed that manufacturing grant affected Chinese companies' export performance positively.

(Brown \& Troutt, 2018) studied on a research which explores the effect of export subsidies on welfare. The current research assumes that imports are restricted by the exporting country. (Brown \& Troutt, 2018) believe that this theory is wrong on many dimensions: it contradicts the ceteris paribus assumption used in economic analysis; it is impractical in a world with rapidly declining shipping prices and free trade; and it conceals the real result of an export subsidy, which leads to inadequate intra-industry trade.

(Defever \& Riano, 2016) analyzed, through a two-country exchange model with heterogeneous companies, the impact of grants subject to export share requirements that is conditioned on exports with at least a fraction of their production on welfare, exports and competitiveness. The model states that this form of government support boosts exports better and gives more protection to domestic companies, but with significant welfare costs, than a regular unconditional export subsidy.

(Broocks \& Van Biesebroeck, 2017)'s paper is another study on export subsidies. They are asserting that it is important for companies learning how to increase or start exporting especially for small economies. Countries which have small and open economies generally provide subsidies to boost export. they studied with the data of company located to Flanders region in Belgium. The main aim of authors is to see if subsidies increase the export outside the EU. The analysis showed that subsidies have a positive effect on export.

The paper of (Srhoj \& Walde, 2020) analyzed the effect of an export subsidies plan created in expectation of participation of a country to the European Union. This plan intended to encourage activity in international market introductions and in technological advancement for emerging or current goods. They found that this new approach has a positive impact on the company's profits, export and net income. Supports were categorized in 2 section which are Technological grants and marketing-oriented grants. Technological grants affect exports and capital stocks positively, while marketing-oriented grants affect exports and intermediate inputs positively. They also found no impacts on wages, and just a minor impact on total factor productivity.

(Sørensen, 2020) proposed a one sector - two country heterogeneous company model. It included companies financed by export promotion organization. The result of the study showed that government support affects export positively, because Via intra-industry reallocations, companies share what was learnt or gained from support with the trading partner. So, the knowledge related to export will spread and many companies will benefit from support directly or indirectly. 
(Esaku, 2020) investigated the impact of physical capital spending on companies' decision to enter the international market and increase export volume. He found that physical capital expenditure at the company level raises the likelihood of small businesses entering export markets. It was also discovered that export knowledge has a huge impact on a firm's decision to invest, most likely as a means of improving manufacturing technology. At the policy stage, it was offered that export subsidies should be targeted to solve capability and technology problems, which make it difficult for small companies to enter the international market and increase their export strength.

\section{KOSGEB SUPPORT}

In order to increase the share and effectiveness of small and medium-sized enterprises in meeting the economic and social needs of the country, to increase their competitiveness and level, to realize the integration in the industry in accordance with economic developments, the Small and Medium Enterprises Development and Support Administration was established. The short name of the organization is KOSGEB (Legislation Information System, 1990). KOSGEB is a Public Institution related to the Ministry of Industry and Technology, has a legal personality and is subject to private law provisions in all its transactions. KOSGEB provides support to businesses in many areas. KOSGEB supports are important for exporting enterprises. These supports can be summarized as follows.

$R \& D$ support is a support provided when businesses find a new product or develop an existing product. There are support items such as R\&D support, lease support, machineryequipment, hardware, raw material, software and service procurement expenses support, personnel expense support, initial capital support, project development support. The total support limit of R\&D support is 750,000 TL. The support rate is $75 \%$. The main purpose of $\mathrm{R} \& \mathrm{D}$ support is to find a prototype of a product. If a prototype of the product is found, The Technological Product Investment Support Program is offered to commercialize this product. The Technological Product Investment Support Program includes supports such as MachineEquipment, Hardware, Consumables, Software and Design Expenses Support, Personnel Expense Support.

Collaboration and Cooperation Support Program is a support created to find common solutions to common problems. For purposes such as joint procurement, joint manufacturing and service delivery, joint marketing, joint laboratory, joint design, businesses need to come together and establish a new business. In order to benefit from the support, projects to be prepared by at least 5 enterprises coming together and if they will operate in the MediumHigh and High Technology Fields, the projects to be prepared by at least 3 companies are supported. The support rate is $60 \%$. In this context, the expenditures of enterprises such as machinery equipment, software and personnel are supported. In the Medium-High and High Technology areas, 300,000 TL non-refundable 1,200,000 TL refundable and 300,000 TL nonrefundable 700,000 TL refundable support is provided to enterprises. Common raw material prices are one of the biggest problems encountered while exporting. If businesses become larger, they will gain an advantage for themselves by providing cheaper raw materials. It is also difficult for small businesses to establish a market research unit. In case the business grows, they will be able to establish units for export by establishing departments under their own roof. The growth of businesses will also bring institutionalization to businesses and therefore have a positive effect on exports. 
Loan interest support, which is generally opened by call, aims to solve the financial problems of businesses. The relevant interest is important for all businesses as well as for exporting businesses. This flexible support, which can be used in places such as the purchase of machinery equipment or raw materials, is important in terms of exports.

The General Support Program is divided into 15 different branches. The total support amount reaches 470,000 TL. Here, branch of this support which has highest contribution to exports in this program can be described as follows. Domestic fair support is important for buyers from abroad to find the products they want to buy and to get to know the business. The total support amount of the fair is 50,000 TL. The amount of this support is 20,000 TL. Instead of supporting individual trips of businesses, supporting the trips made by institutions such as Chambers of commerce contributes to exports by providing a more effective foreign trade by communicating on the basis of institutions and reaching the purpose of the trip. It is important for businesses to be able to print catalogs, to advertise in printed publications abroad and to make business promotions. Thus, it enables businesses to reach a wider audience and thus increase their exports. The amount of support is 25,000 TL. Qualified staff support amount is 50,000 TL. When businesses want to employ qualified staff, who can speak a language with a high level of education, they usually face cost problems due to high wages. It is an important support in solving this problem. It is impossible for businesses to know the legislation in foreign countries completely, or they do not have personnel to do such work. For this reason, businesses may have to get support from outside. If they want to train their own staff to get support in this regard, they can benefit from training support, if they only want to receive consultancy, they can benefit from consultancy support. The amount of consultancy support is 22,500 and the amount of training support is 20,000 TL. It is important for businesses to find opportunities to reduce their costs while competing in the foreign market. Logistics support is a support of 40,000 TL that reduces the transportation costs of the enterprises and thus increases their competitiveness in exports. One of the most important problems of SMEs is finding customers. Thanks to the matching support, companies that want to export products can find customers through the matching Centers. The support amount is $30,000 \mathrm{TL}$.

The European Business Network is a structure that has many companies within itself, allows these companies to sell their products, and provides mentorship to businesses rather than financial support. Being in such a wide network will give businesses a great advantage in finding customers. In addition, it is an important support to Turkey in terms of attracting external funding by writing projects.

\section{OBJECTIVE, IMPORTANCE, AND SCOPE OF THE RESEARCH}

The aim of the research is to investigate the effects of KOSGEB supports on the foreign trade of SMEs and how important KOSGEB supports are for SMEs.

As known, the positive effects of exports on the economy are quite high. Increasing these positive effects will contribute to economies in many aspects, such as decrease in unemployment and increase in income level. Therefore, this research was aimed to work on how to remove the obstacles in front of exports by KOSGEB and then how to increase exports. 
Exchange bottlenecks, on occasion, emerge in Turkish Economy. These bottlenecks cause some damages on the economy both in general and regionally. In order to minimize these damages, some support should be provided by the state. For this reason, this study is important in terms of determining the needs of SMEs and seeing what kind of support can be provided for these problems in terms of KOSGEB.

Within the scope of the research, SMEs registered to the Southeastern Anatolia Exporters Union and located in Gaziantep were included in the analysis. It was seen that there are 2321 companies registered in the database.

The sample size was determined by considering the population number of 2321 . With a margin of error as $10 \%$, it was seen that 92 companies would be sufficient to answer the questionnaire at $95 \%$ confidence level. However, the number of surveys answered was 103 and the survey results were evaluated by considering these 103 companies.

The questionnaire method was used as the research method in this paper. Survey questions were directed to SMEs and their problems, situations and needs were tried to be analyzed. In the survey, the enterprises were asked 16 questions, 1 of which was openended. In this context, the first 12 questions are about getting to know the SMEs, the 13th question is about understanding the problems faced by SMEs in exports, the 14th question is on measuring the effects of KOSGEB supports on exports and the 15th question is on measuring expectations of SMEs from KOSGEB. 16. The question is an open-ended question and it is the question asked to see the expectations, suggestions, opinions of the SMEs from KOSGEB to increase exports.

\section{METHODS}

Reliability test provides information about whether the data used in an analysis is consistent. In other words, it shows whether individual's answers to survey questions are consistent or not. Under the same conditions, a reliable test should give the same results when re-applied. To put it another way, reliability analysis is a requirement for obtaining reliable outcomes from the analysis to be performed. In sum, unreliable data cannot be used in analysis. Briefly, reliability analysis is used to see if the scale questions are reliable. The value, which is $\alpha$, is between 0 and 1 . The $\alpha$ value can be seen below (Cronbach, 1951; Cronbach \& Shavelson, 2004).

$0 \leq \alpha<0.4$ is not reliable,

$0.4 \leq \alpha<0.6$ reliability is low,

$0.6 \leq \alpha<0.8$ is reliable

$0.8 \leq \alpha<1$ is highly reliable.

T Test, ANOVA Analysis and TUKEY Analysis are also other methods for questionnaire analysis. The main aim of these analyses is to reveal if there is a significant difference between groups.

The t-test is one of the most often used predictive research techniques. This test is a foundational component in many univariate analyses and one of the most often used methods in hypothesis testing studies. It is used to test if the variance between constant variables or classes is statistically important, or to establish whether the average observable value differs from the expected value. In brief, $\mathrm{T}$ test compares two means, so 
it reveals whether these 2 means are different or not. To put it another way, it shows if the emerging differences resulted by chance or not (Student, 1908).

The purpose of ANOVA test is to see if there is a significant difference between the means of independent groups. ANOVA is used for comparison of a numerical variable in at least three groups. This examination mostly examines when one group at least differs from the other. In sum, ANOVA analysis is similar to T test, if there is more than 2 groups this method is used. This analysis usually evaluates the difference between groups.

When the ANOVA test shows a statistically significant $P$ value, TUKEY test is used to determine the difference among the groups. Tukey analysis is one of post hoc analyses. The main aim of post-hoc analysis is to compare 2 groups. There are some issues that need to be taken into account while examining the mean of the groups. These issues are deviations and averages of the groups. Tukey analysis is a more specific analysis than ANOVA, and TUKEY method is used to see significant difference groups individually (Lindman, 1974).

Within the scope of the research, the hypotheses were formed as follows.

$\mathrm{H}_{1}$ : There are differences between the problems faced by SME groups who benefit and do not benefit from the programs offered by KOSGEB.

$\mathrm{H}_{2}$ : There are differences between the problems SME groups face according to the sectors in which SMEs operate.

$\mathrm{H}_{3}$ : There are differences among the problems SME groups face according to the export amounts.

$\mathrm{H}_{4}$ : There are differences between the problems SME groups face according to the net sales amounts.

$\mathrm{H}_{5}$ : There are differences between the problems faced by SME groups according to the export regions.

$\mathrm{H}_{6}$ : There are differences between the problems SME groups face according to the most important competitors.

\section{RESULTS}

Results of the analysis can be seen below. According to reliability analysis, as seen below, questions are reliable, because Cronbach's Alpha value is 0,881. As seen, the value is between $0.8 \leq \alpha<1$. It means the values is highly reliable, so further analysis can be implemented to questionaries result.

Table 1 Reliability analysis

\begin{tabular}{ll}
\hline Cronbach's Alpha & Number of Questions \\
\hline Source: Own calculation based on available data
\end{tabular}

As seen in the Table 2, the problems faced by SMEs were analyzed according to whether they have benefitted from KOSGEB supports or not in the last 3 years. As a result, it was observed that there was a significant difference between the two groups regarding High Salaries. It shows that businesses that benefit from KOSGEB supports have less problems in this regard than those that do not. 
The skilled staff issue is crucial for companies. It is clear that skilled staff are working on the market for a higher wage. While supporting employees, it is also important to be more selective to help the employees who contribute to firms more effectively, instead of supporting both graduates and undergraduate students and supplying a small amount of support.

Table 2 Analysis of the problems faced by SMEs in cases of benefiting and not benefiting from KOSGEB supports (Last 3 years)

\begin{tabular}{|c|c|c|c|c|c|c|c|}
\hline \multicolumn{2}{|c|}{$\begin{array}{l}\text { Benefitting or not benefiting from } \\
\text { KOSGEB support }\end{array}$} & $\mathrm{N}$ & Mean & $\begin{array}{c}\text { Std. } \\
\text { Deviation }\end{array}$ & $\begin{array}{c}\text { Std. Error } \\
\text { Mean }\end{array}$ & $\mathrm{T}$ & $\mathrm{P}$ \\
\hline \multirow{2}{*}{ Bureaucratic Barriers } & Yes & 52 & 3.4423 & 1.17846 & 0.16342 & \multirow{2}{*}{3.607} & \multirow{2}{*}{0.060} \\
\hline & No & 51 & 3.5098 & 0.94599 & 0.13247 & & \\
\hline \multirow{2}{*}{$\begin{array}{l}\text { Problems in accessing } \\
\text { markets }\end{array}$} & Yes & 52 & 3.3846 & 1.06925 & 0.14828 & \multirow{2}{*}{0.002} & \multirow{2}{*}{0.963} \\
\hline & No & 51 & 3.4314 & 1.08176 & 0.15148 & & \\
\hline \multirow{2}{*}{ Raw material costs } & Yes & 52 & 4.2308 & 1.07768 & 0.14945 & \multirow{2}{*}{0.406} & \multirow{2}{*}{0.526} \\
\hline & No & 51 & 4.1373 & 1.00039 & 0.14008 & & \\
\hline \multirow{2}{*}{ Financial problems } & Yes & 52 & 3.7308 & 1.06854 & 0.14818 & \multirow{2}{*}{1.728} & \multirow{2}{*}{0.192} \\
\hline & No & 51 & 3.4706 & 1.22234 & 0.17116 & & \\
\hline Qualified personnel or & Yes & 52 & 3.3846 & 1.17413 & 0.16282 & \multirow{2}{*}{0.149} & \multirow{2}{*}{0.700} \\
\hline language problems & No & 51 & 2.7647 & 1.30519 & 0.18276 & & \\
\hline \multirow{2}{*}{ High Staff Salaries } & Yes & 52 & 2.5490 & 1.23796 & 0.17335 & \multirow{2}{*}{4.831} & \multirow{2}{*}{0.030} \\
\hline & No & 51 & 2.9423 & 1.03684 & 0.14378 & & \\
\hline Problems in accessing & Yes & 52 & 3.5577 & 1.03684 & 0.14378 & \multirow{2}{*}{1.102} & \multirow{2}{*}{0.296} \\
\hline Incentives and Supports & No & 51 & 3.8824 & 1.01286 & 0.14183 & & \\
\hline \multirow{2}{*}{ High logistics costs } & Yes & 52 & 3.8462 & 1,10940 & 0.15385 & \multirow{2}{*}{2.106} & \multirow{2}{*}{0.150} \\
\hline & No & 51 & 3.8431 & 0.90272 & 0.12641 & & \\
\hline \multirow{2}{*}{ High production costs } & Yes & 52 & 4.0962 & 0.97538 & 0.13526 & \multirow{2}{*}{0.000} & \multirow{2}{*}{0.994} \\
\hline & No & 51 & 4.1569 & 0.94599 & 0.13247 & & \\
\hline
\end{tabular}

Source: Own calculation based on available data

The problems faced by SMEs in the different sectors have been analyzed. The main purpose is to see whether there is a difference between the sectors compared. As a result, when the problems were taken into consideration, no significant difference was observed between the groups.

As seen in the Table 3, the problems faced by SMEs according to export volumes were analyzed. The main purpose is to see if there is a difference in the problems encountered according to export volumes. As a result, considering the problems, a significant difference was found between the groups in terms of Qualified personnel or language problems and high personnel salaries. After considering these results, Tukey analysis should be implemented. 
Table 3 Analysis of the problems faced by SMEs - According to export volumes - (ANOVA)

\begin{tabular}{|c|c|c|c|c|c|c|c|}
\hline & & $\mathrm{N}$ & Mean & Std. Dev & Std. Err & $\mathrm{f}$ & $\mathrm{p}$ \\
\hline Bureaucratic & $0-499,000 \$$ & 49 & 3.4898 & 1.12031 & 0.16004 & 0.382 & 0.766 \\
\hline \multirow[t]{4}{*}{ Barriers } & $500,000-999,999 \$$ & 20 & 3.3000 & 1.26074 & 0.28191 & & \\
\hline & $1,000,000-4,999,999 \$$ & 23 & 3.4783 & 0.89796 & 0.18724 & & \\
\hline & $5,000,000 \$$ and more & 11 & 3.7273 & 0.78625 & 0.23706 & & \\
\hline & Total & 103 & 3.4757 & 1.06499 & 0.10494 & & \\
\hline \multirow{5}{*}{$\begin{array}{l}\text { Problems in } \\
\text { accessing } \\
\text { markets }\end{array}$} & $0-499,000 \$$ & 49 & 3.5306 & 1.13838 & 0.16263 & 0.603 & 0.615 \\
\hline & $500,000-999,999 \$$ & 20 & 3.1500 & 1.18210 & 0.26433 & & \\
\hline & $1,000,000-4,999,999 \$$ & 23 & 3.3913 & 0.94094 & 0.19620 & & \\
\hline & $5,000,000 \$$ and more & 11 & 3.3636 & 0.80904 & 0.24393 & & \\
\hline & Total & 103 & 3.4078 & 1.07043 & 0.10547 & & \\
\hline \multirow{5}{*}{$\begin{array}{l}\text { Raw material } \\
\text { costs }\end{array}$} & $0-499,000 \$$ & 49 & 4.0612 & 1.12561 & 0.16080 & 0.436 & 0.728 \\
\hline & $500,000-999,999 \$$ & 20 & 4.3000 & 1.21828 & 0.27242 & & \\
\hline & $1,000,000-4,999,999 \$$ & 23 & 4.3043 & 0.87567 & 0.18259 & & \\
\hline & $5,000,000 \$$ and more & 11 & 4.2727 & 0.46710 & 0.14084 & & \\
\hline & Total & 103 & 4.1845 & 1.03609 & 0.10209 & & \\
\hline \multirow{5}{*}{$\begin{array}{l}\text { Financial } \\
\text { problems }\end{array}$} & $0-499,000 \$$ & 49 & 3.7959 & 1.17224 & 0.16746 & 1.304 & 0.277 \\
\hline & $500,000-999,999 \$$ & 20 & 3.6500 & 1.34849 & 0.30153 & & \\
\hline & $1,000,000-4,999,999 \$$ & 23 & 3.3043 & 1.06322 & 0.22170 & & \\
\hline & $5,000,000 \$$ and more & 11 & 3.2727 & 0.64667 & 0.19498 & & \\
\hline & Total & 103 & 3.6019 & 1.14908 & 0.11322 & & \\
\hline \multirow{5}{*}{$\begin{array}{l}\text { Qualified } \\
\text { personnel or } \\
\text { language } \\
\text { problems }\end{array}$} & $0-499,000 \$$ & 49 & 3.5918 & 1.20621 & 0.17232 & 8.096 & 0.000 \\
\hline & $500,000-999,999 \$$ & 20 & 3.1000 & 0.96791 & 0.21643 & & \\
\hline & $1,000,000-4,999,999 \$$ & 23 & 2.2609 & 1.17618 & 0.24525 & & \\
\hline & $5,000,000 \$$ and more & 11 & 2.4545 & 1.21356 & 0.36590 & & \\
\hline & Total & 103 & 3.0777 & 1.27333 & 0.12546 & & \\
\hline \multirow{5}{*}{$\begin{array}{l}\text { High Staff } \\
\text { Salaries }\end{array}$} & $0-499,000 \$$ & 49 & 3.2041 & 1.09886 & 0.15698 & 7.157 & 0.000 \\
\hline & $500,000-999,999 \$$ & 20 & 2.7000 & 1.08094 & 0.24170 & & \\
\hline & $1,000,000-4,999,999 \$$ & 23 & 2.0435 & 0.97600 & 0.20351 & & \\
\hline & $5,000,000 \$$ and more & 11 & 2.2727 & 1.00905 & 0.30424 & & \\
\hline & Total & 103 & 2.7476 & 1.15231 & 0.11354 & & \\
\hline \multirow{5}{*}{$\begin{array}{l}\text { Problems in } \\
\text { accessing } \\
\text { Incentives and } \\
\text { Supports }\end{array}$} & $0-499,000 \$$ & 49 & 3.8571 & 1.00000 & 0.14286 & 0.934 & 0.427 \\
\hline & $500.000-999,999 \$$ & 20 & 3.6500 & 1.30888 & 0.29267 & & \\
\hline & $1,000,000-4,999,999 \$$ & 23 & 3.4348 & 0.94514 & 0.19707 & & \\
\hline & $5,000,000 \$$ and more & 11 & 3.8182 & 0.75076 & 0.22636 & & \\
\hline & Total & 103 & 3.7184 & 1.03296 & 0.10178 & & \\
\hline \multirow{5}{*}{$\begin{array}{l}\text { High logistics } \\
\text { costs }\end{array}$} & $0-499,000 \$$ & 49 & 3.6531 & 1.16460 & 0.16637 & 1.467 & 0.228 \\
\hline & $500,000-999,999 \$$ & 20 & 4.0000 & 1.07606 & 0.24061 & & \\
\hline & $1,000,000-4,999,999 \$$ & 23 & 3.9130 & 0.66831 & 0.13935 & & \\
\hline & $5,000,000 \$$ and more & 11 & 4.2727 & 0.46710 & 0.14084 & & \\
\hline & Total & 103 & 3.8447 & 1.00740 & 0.09926 & & \\
\hline \multirow{5}{*}{$\begin{array}{l}\text { High production } \\
\text { costs }\end{array}$} & $0-499,000 \$$ & 49 & 4.0204 & 1.12712 & 0.16102 & 0.652 & 0.584 \\
\hline & $500,000-999,999 \$$ & 20 & 4.3000 & 0.97872 & 0.21885 & & \\
\hline & $1,000,000-4,999,999 \$$ & 23 & 4.0870 & 0.66831 & 0.13935 & & \\
\hline & $5,000,000 \$$ and more & 11 & 4.3636 & 0.50452 & 0.15212 & & \\
\hline & Total & 103 & 4.1262 & 0.95671 & 0.09427 & & \\
\hline
\end{tabular}

Source: Own calculation based on available data 
Table 4 Analysis of the problems faced by SMEs - According to export volumes (Tukey significance analysis)

\begin{tabular}{lccc}
\hline & Export Volume & Tukey Sig. \\
\hline \multirow{2}{*}{ Qualified personnel or language problems } & \multirow{2}{*}{$0-499,000 \$$} & $\begin{array}{c}1.000 .000-4.999 .999 \$ \\
5.000 .000 \$ \text { and more }\end{array}$ & 0.000 \\
& & 0.021 \\
\hline \multirow{2}{*}{ High Staff Salaries } & \multirow{2}{*}{$0-499,000 \$$} & $\begin{array}{c}1.000 .000-4.999 .999 \$ \\
5.000 .000 \$ \text { and more }\end{array}$ & 0.000 \\
& & 0.048 \\
\hline
\end{tabular}

Source: Own calculation based on available data

Table 5 Analysis of the problems faced by SMEs - According to export volumes

\begin{tabular}{lll}
\hline & Export Vol. & Mean \\
\hline \multirow{2}{*}{ Qualified personnel or language problems } & $0-499,000 \$ *$ & 3.5918 \\
& $1,000,000-4,999,999 \$ *$ & 2.2609 \\
& $5,000,000 \$$ and more* & 2.4545 \\
\hline \multirow{2}{*}{ High Staff Salaries } & $0-499,000 \$$ & 3.2041 \\
& $1,000,000-4,999,999 \$$ & 2.0435 \\
\hline
\end{tabular}

Source: Own calculation based on available data

As seen in tables 4 and 5 above, significance was found in the ANOVA analysis for "Qualified personnel or language problems" and "High Staff Salaries", and hence the TUKEY analysis was applied. As seen from the above table, there is a significant difference in terms of qualified personnel or language problems between those with export volume of 0-499,000 \$ and those with 1,000,000 \$4,999,999 and 5,000,000 \$ and more.

In terms of High Staff Salaries, a significant difference was determined between those with export volumes of 500,000-999,999 \$ and those with export volumes of 1,000,000$4,999,999$ \$ and 5,000,000 \$ and above. Similarly, it was observed that there is a significant difference between SMEs with an export volume of 500,000-999,999 and those with an export volume of \$1,000,000- \$4,999,999.

Test results show that companies with low export level experience greater problems with Qualified personnel or language problems. Similarly, high personnel wages pose a bigger problem for businesses with an export volume of up to $\$ 500,000$. For this reason, while providing support, businesses with an export volume of up to $\$ 500,000$ can be privileged and more support should be given in this regard. For example, these companies can be made more attractive than other companies by providing salary support and ensuring that the business pays higher salaries to qualified personnel.

The problems encountered were analyzed considering the net sales volumes. The main purpose is to see whether there are differences in terms of problems according to the net sales volumes encountered. As a result, when the problems were taken into consideration, no significant difference was observed between the groups. However, in terms of net sales volumes, no significant difference was detected in the problems encountered. 
Table 6 Analysis of the problems faced by SMEs - According to the most exported region - (Anova)

\begin{tabular}{|c|c|c|c|c|c|c|c|}
\hline & & $\mathrm{N}$ & Mean & Std. Deviation & Std. Error & $\mathrm{f}$ & $p$ \\
\hline \multirow{6}{*}{$\begin{array}{l}\text { Bureaucratic } \\
\text { Barriers }\end{array}$} & Europe Zone & 28 & 3.7857 & 0.95674 & 0.18081 & \multirow{6}{*}{1.725} & \multirow{6}{*}{0.150} \\
\hline & America Zone & 11 & 3.9091 & 0.83121 & 0.25062 & & \\
\hline & Middle East Zone & 39 & 3.2821 & 1.09901 & 0.17598 & & \\
\hline & Asia Zone & 13 & 3.2308 & 1.16575 & 0.32332 & & \\
\hline & Other & 12 & 3.2500 & 1.13818 & 0.32856 & & \\
\hline & Total & 103 & 3.4757 & 1.06499 & 0.10494 & & \\
\hline \multirow{6}{*}{$\begin{array}{l}\text { Problems in } \\
\text { accessing markets }\end{array}$} & Europe Zone & 28 & 3.3571 & 1.02611 & 0.19392 & \multirow{6}{*}{1.269} & \multirow{6}{*}{0.287} \\
\hline & America Zone & 11 & 3.7273 & 1.00905 & 0.30424 & & \\
\hline & Middle East Zone & 39 & 3.2821 & 1.07480 & 0.17211 & & \\
\hline & Asia Zone & 13 & 3.1538 & 1.28103 & 0.35529 & & \\
\hline & Other & 12 & 3.9167 & 0.90034 & 0.25990 & & \\
\hline & Total & 103 & 3.4078 & 1.07043 & 0.10547 & & \\
\hline \multirow{6}{*}{ Raw material costs } & Europe Zone & 28 & 4.3214 & 1.05597 & 0.19956 & \multirow{6}{*}{1.442} & \multirow{6}{*}{0.226} \\
\hline & America Zone & 11 & 4.7273 & 0.46710 & 0.14084 & & \\
\hline & Middle East Zone & 39 & 3.9487 & 1.14590 & 0.1834 & & \\
\hline & Asia Zone & 13 & 4.2308 & 0.92681 & 0.2570 & & \\
\hline & Other & 12 & 4.0833 & 0.99620 & 0.28758 & & \\
\hline & Total & 103 & 4.1845 & 1.03609 & 0.10209 & & \\
\hline \multirow{6}{*}{ Financial problems } & Europe Zone & 28 & 3.5357 & 0.96156 & 0.18172 & \multirow{6}{*}{0.262} & \multirow{6}{*}{0.902} \\
\hline & America Zone & 11 & 3.4545 & 1.50756 & 0.45455 & & \\
\hline & Middle East Zone & 39 & 3.5641 & 1.20950 & 0.19367 & & \\
\hline & Asia Zone & 13 & 3.7692 & 1.09193 & 0.30285 & & \\
\hline & Other & 12 & 3.8333 & 1.19342 & 0.34451 & & \\
\hline & Total & 103 & 3.6019 & 1.14908 & 0.11322 & & \\
\hline \multirow{6}{*}{$\begin{array}{l}\text { Qualified personnel } \\
\text { or language } \\
\text { problems }\end{array}$} & Europe Zone & 28 & 3.1786 & 0.94491 & 0.17857 & \multirow{6}{*}{2.534} & \multirow{6}{*}{0.045} \\
\hline & America Zone & 11 & 3.3636 & 1.36182 & 0.41060 & & \\
\hline & Middle East Zone & 39 & 2.6923 & 1.37943 & 0.22089 & & \\
\hline & Asia Zone & 13 & 3.0000 & 1.15470 & 0.32026 & & \\
\hline & Other & 12 & 3.9167 & 1.31137 & 0.37856 & & \\
\hline & Total & 103 & 3.0777 & 1.27333 & 0.12546 & & \\
\hline \multirow{6}{*}{ High Staff Salaries } & Europe Zone & 28 & 2.6786 & 0.86297 & 0.16309 & \multirow{6}{*}{1.742} & \multirow{6}{*}{0.147} \\
\hline & America Zone & 11 & 3.0909 & 1.13618 & 0.34257 & & \\
\hline & Middle East Zone & 39 & 2.5128 & 1.27469 & 0.20411 & & \\
\hline & Asia Zone & 13 & 2.6923 & 1.18213 & 0.32786 & & \\
\hline & Other & 12 & 3.4167 & 1.16450 & 0.33616 & & \\
\hline & Total & 103 & 2.7476 & 1.15231 & 0.11354 & & \\
\hline & Europe Zone & 28 & 3.7143 & 0.93718 & 0.17711 & & \\
\hline & America Zone & 11 & 3.2727 & 1.48936 & 0.44906 & & \\
\hline Problems in & Middle East Zone & 39 & 3.7436 & 0.96567 & 0.15463 & & \\
\hline accessing Incentives & Asia Zone & 13 & 3.6923 & 1.03155 & 0.28610 & 0 & $0.4 / 3$ \\
\hline & Other & 12 & 4.0833 & 0.99620 & 0.28758 & & \\
\hline & Total & 103 & 3.7184 & 1.03296 & 0.10178 & & \\
\hline & Europe Zone & 28 & 3.7857 & 0.95674 & 0.18081 & & \\
\hline & America Zone & 11 & 4.8182 & 0.40452 & 0.12197 & & \\
\hline & Middle East Zone & 39 & 3.4872 & 0.94233 & 0.15089 & & \\
\hline High logistics costs & Asia Zone & 13 & 4.0769 & 0.95407 & 0.26461 & 4.645 & 0.002 \\
\hline & Other & 12 & 4.0000 & 1.20605 & 0.34816 & & \\
\hline & Total & 103 & 3.8447 & 1.00740 & 0.09926 & & \\
\hline & Europe Zone & 28 & 3.9643 & 0.83808 & 0.15838 & & \\
\hline & America Zone & 11 & 4.5455 & 0.68755 & 0.20730 & & \\
\hline High production & Middle East Zone & 39 & 4.0000 & 0.94591 & 0.15147 & & \\
\hline costs & Asia Zone & 13 & 4.4615 & 0.87706 & 0.24325 & 1.319 & 0.208 \\
\hline & Other & 12 & 4.1667 & 1.40346 & 0.40514 & & \\
\hline & Total & 103 & 4.1262 & 0.95671 & 0.09427 & & \\
\hline
\end{tabular}

Source: Own calculation based on available data 
The problems encountered were analyzed by considering the regions where the most exports are made to. As a result, considering the problems, no significant difference was observed between the groups in terms of qualified personnel or language problems and high logistics costs. Tukey analysis is required to see between which groups this significant difference exists.

Table 7 Analysis of problems faced by SMEs - According to the most exported region (Tukey significance analysis)

\begin{tabular}{llc}
\hline & The most exported region & Tukey Sig. \\
\hline Qualified personnel or language problems & Middle East Zone & 0.028 \\
\hline \multirow{2}{*}{ High logistics costs } & Europe Zone & 0.022 \\
& America Zone & 0.001 \\
\hline
\end{tabular}

Source: Own calculation based on available data

Table 8 Analysis of problems faced by SMEs - According to the most exported region (Tukey)

\begin{tabular}{lll}
\hline & The most exported region & Mean \\
\hline \multirow{2}{*}{ Qualified personnel or language problems } & Middle East Zone $^{*}$ & 2.692 \\
& Other $^{*}$ & 3.917 \\
\hline \multirow{3}{*}{ High logistics costs } & Europe Zone $^{*}$ & 3.786 \\
& America Zone & 4.818 \\
\hline
\end{tabular}

Source: Own calculation based on available data

When TUKEY analysis was carried out, there is a significant difference for qualified personnel or language problems between the Middle East and other regions; for the problems of high logistics costs, there is a significant difference between the European Region - America Region and America Region - Middle East Region.

The results of tests indicate that businesses exporting to another area have more difficulty with qualified staff or with language issues. So, companies exporting other zones can be prioritized while providing incentives and grants by the government. In addition, companies exporting to America zone should be provided with more logistic support due to the high cost. Providing consultancy service about trade legislation will also accelerate and facilitate export.

The problems encountered were analyzed by considering the most important competitors of the SMEs. As a result, no significant difference was found between the groups when the problems were taken into account. 
Table 9 Hypothesis results

\begin{tabular}{ll}
\hline Hypothesis & Result
\end{tabular}

$\mathrm{H}_{1}$ : There are differences between the problems faced by SME groups who benefit Accepted from and do not benefit from the programs offered by KOSGEB.

$\mathrm{H}_{2}$ : There are differences between the problems SME groups face according to the Rejected sectors in which SMEs operate.

$\mathrm{H}_{3}$ : There are differences among the problems SME groups face according to the Accepted export amounts.

$\mathrm{H}_{4}$ : There are differences between the problems SME groups face according to the Rejected net sales amounts.

$\mathrm{H}_{5}$ : There are differences between the problems faced by SME groups according to Accepted the export regions.

$\mathrm{H}_{6}$ : There are differences between the problems SME groups face according to the Rejected most important competitors.

\section{CONCLUSION}

Export plays an important role in the development of the country's economies. The export made by companies will not only contribute to the relevant sector, but also to the entire country's economy as it provides foreign currency inflow to the country. KOSGEB has an important role as well as many public institutions in terms of SMEs not having problems in exports and increasing their exports even more in their companies that do not have problems. Therefore, some actions should be taken considering the needs of the SMEs.

In view of the responses of the SMEs involved in the study, the problems faced by companies can be seen. One of the most important problems, in this context, was the problem in accessing markets. So, market research conducted by KOSGEB will make an important contribution to increasing exports. International business trip support is also important for SMEs to find new markets. The fact that matching support is provided by KOSGEB contributes to finding new buyers, customers. Apart from this, it should be ensured that SMEs are included in the COSME network and thus reach many buyers and sellers in a wide network.

Another problem faced by SMEs were financial problems. In order to solve financial problems, credit support should be provided for the needs of SMEs. However, considering the possibility that the enterprises will behave unconscionably while using the related loan, it is necessary to follow up where the loan will be spent. Otherwise, the relevant support will go to the personal and luxury needs of the companies' authorities (for example, the purchase of higher model vehicles, etc.) and the current account deficit will grow further.

Another problem faced by SMEs is the inability to access support. Therefore, the promotion of support should increase and the application processes for support should become easier.

The lack of research and development is another issue. However, the importance of this issue should be explained to the enterprises operating in sectors such as machinery and software that have strategic importance and should be encouraged in this regard. Companies are of the opinion that R\&D, Innovation, Industrialization Support Program is important for export. One of the biggest reasons is that the return of technology-based products is both easier to export and their return is high. Today, the market value of some big companies 
working on technology-based companies such as Apple and Amazon, is more than one trillion dollars. Therefore, supporting R\&D activities will make a great contribution to exports.

It is another fact that SMEs have problems with raw material prices and production costs. Considering the economies of scale, it can be seen that large companies experience fewer problems in terms of supply and cost than other companies. For this purpose, the merger of small businesses and establishing a new company will provide many advantages such as reducing their costs and facilitating the procurement process.

In order to increase export volumes, the promotion of both the enterprise and their products should be increased. In this context, supports such as fair support and promotional support are important in terms of increasing exports, as can be seen from the survey results.

It is impossible to know everything about foreign markets. In this respect, it is essential to get support from professionals. The fact that this support can be obtained from KOSGEB under the name of training support or consultancy support will again contribute positively to exports.

Although it was seen that a wide sample size was reached in the research, efforts should be made to increase the promotion of the existing supports, and a wider population should be reached. So, KOSGEB's promotional activities should be increased.

Although it is very important to support SMEs financially, as can be seen from the results of the survey, SMEs also need consultancy and training. Although consultancy support is provided to solve this problem, the number of consultants who will provide quality information or conduct research is not enough in the market, unlike in KOSGEB, which has a very wide network of information about the markets. For this, such support should be provided to enterprises by KOSGEB.

In this paper six hypotheses are created. While " $\mathrm{H}_{1}$ : There are differences between the problems faced by SME groups who benefit from and do not benefit from the programs offered by KOSGEB. $\mathrm{H}_{3}$ : There are differences among the problems SME groups face according to the export amounts. $\mathrm{H}_{5}$ : There are differences between the problems faced by SME groups according to the export regions." are accepted, " $\mathrm{H}_{2}$ : There are differences between the problems SME groups face according to the sectors in which SMEs operate. $\mathrm{H}_{4}$ : There are differences between the problems SME groups face according to the net sales amounts. $\mathrm{H}_{6}$ : There are differences between the problems SME groups face according to the most important competitors." are rejected.

In the $\mathrm{H}_{1}$ hypothesis, the problems faced by SMEs in the last 3 years were evaluated in the test results according to whether or not they have been supported by KOSGEB. As a result, it was seen that there was a significant difference in the salary rates between the two classes. The problem of qualified personnel, language and high personnel salaries were another striking issue. It was quite natural that these problems are seen at the same time in companies. Because it was obvious that qualified personnel work for a higher salary in the market. Therefore, while supporting the staff, instead of supporting all graduates and undergraduates and providing a low amount of support, it is necessary to be more selective and give higher support to the staff who will contribute to the companies at a higher rate. Therefore, within the scope of the Business Development Support Program, privilege that should be given to the company exporting for qualified personnel will have a positive effect. 
In the $\mathrm{H}_{2}$ hypothesis, the difficulties that SMEs face in various sectors have been investigated. The main goal is to see if there is a difference between the sectors that are being compared. As a consequence, when the issues were considered, there was no significant difference between the sectors.

In the third hypothesis, the issues that SMEs face were examined by looking at export volumes. It was seen that there was a significant difference in terms of skilled staff or language issues between those with export volumes of 0-499,000 dollars and those with 1,000,000 dollars, 4,999,999 dollars, and 5,000,000 dollars and more. There was a significant difference, with regards to high staff salaries, between those with export volumes of 500,000999,999 \$ and those with export volumes of 1,000,000- 4,999,999 \$ and 5,000,000 \$ and above. Similarly, a major difference was found between SMEs with export volumes of $\$ 500,000-999,999$ and those with export volumes of $\$ 1,000,000-\$ 4,999,999$. According to test results, companies with a low export level have more issues with qualified workers or language barriers. Similarly, for companies with an export amount of up to $\$ 500,000$, high personnel wages are a bigger problem. As a result, companies with export volumes of up to $\$ 500,000$ could be given priority, and further assistance should be provided in this region. For example, these businesses can be made more appealing than others by offering wage support and ensuring that eligible employees are paid higher wages.

In the fourth hypothesis, the problems that SMEs face were examined by regarding the net sales volumes. Consequently, when the problems were taken into account, there was no significant difference between the classes.

In the $\mathrm{H}_{5}$ hypothesis, issues which companies encountered were analyzed by regarding the regions where the most exports are directed. There is a significant difference between the Middle East and other regions in terms of skilled workers or language issues; there is a significant difference between the European Area - America Region and the America Region - Middle East Region in terms of high logistical costs. Test findings show that companies exporting to other regions have more trouble finding skilled workers or dealing with language barriers. As a result, while businesses exporting to other zones can be prioritized while the government provides incentives and grants. In addition, because of the high cost, companies exporting to the Americas zone should be given more logistic support.

The aim of $\mathrm{H}_{6}$ hypothesis is to check if there are any differences between company groups, considering their most important competitors. when the problems were analyzed, there was no significant difference detected between the groups.

Considering the results, it was seen that there are some problems arising for companies and these problems should be solved. It is obvious that the majority of KOSGEB supports are effective on exports and will play an active role in solving these problems.

\section{REFERENCES}

Alesina, A., \& Rodrik, D. (1994). Distributive Politics and Economic Growth. The Quarterly Journal of Economics, 109(2), 465-490.

Anderson, J. E. (1979). A Theoretical Foundation for the Gravity Equation. The American Economic Review, 69(1), 106-116.

Astarlioğlu, M. (2017). Yerel Piyasa Koşullarinin Ihracat Performansi Üzerine Etkileri: Hollanda Ve Türkiye'deki Kobi'ler Üzerine Kantitatif Bir Çalişma [The Effects of Local Market Conditions on Export Performance: A Quantitative Study on SMEs in the Netherlands and Turkey]. Hacettepe Üniversitesi Iktisadi ve İdari Bilimler Fakültesi Dergisi, 35(3), 1-18. 
Bergstrand, J. H. (1985). The Gravity Equation in International Trade: Some Microeconomic Foundations and Empirical Evidence. The Review of Economics and Statistics, 67(3), 474-481.

Bernard, A. B., Jensen, J. B., Redding, S. J., \& Schott, P. K. (2007). Firms in International Trade. Journal of Economic Perspectives, 21(3), 105-130.

Broocks, A., \& Van Biesebroeck, J. (2017). The impact of export promotion on export market entry. Journal of International Economics, 107, 19-33.

Brown, L. K., \& Troutt, E. (2018). A re-analysis of the trade and welfare effects of export subsidies. Applied Economics Letters, 25(6), 420-424.

Çinar, B., \& Koç, F. (2017). Pazarlama Yeteneklerinin Ihracat Performansi Üzerindeki Etkisi [The Impact of Marketing Capabilities on Export Performance]. Bolu Abant İzet Baysal Üniversitesi Sosyal Bilimler Enstitüsü Dergisi, 17(3), 115-143.

Coase, R. H. (1960). The Problem of Social Cost. The Journal of Law and Economics, 3, 1-44.

Cronbach, L. J. (1951). Coefficient alpha and the internal structure of tests. Psychometrika, 16(3), 297-334.

Cronbach, L., \& Shavelson, R. (2004). My Current Thoughts on Coefficient Alpha and Successor Procedures. Educational and Psychological Measurement - EDUC PSYCHOL MEAS, 64, 391-418.

Deardorff, A. V. (1995). Determinants of Bilateral Trade: Does Gravity Work in a Neoclassical World? (No. w5377). National Bureau of Economic Research.

Defever, F., \& Riano, A. (2016). Protectionism Through Exporting: Subsidies with Export Share Requirements in China. Social Science Research Network.

Defever, F., \& Riaño, A. (2017). Subsidies with export share requirements in China. Journal of Development Economics, 126, 33-51.

Esaku, S. (2020). Investments, export entry and export intensity in small manufacturing firms. Journal of Industrial and Business Economics, 47(4), 677-697.

Evenett, S., \& Venables, A. (2002). Export Growth in Developing Countries: Market Entry and Bilateral Trade Flows.

Fryges, H., \& Wagner, J. (2010). Exports and Profitability: First Evidence for German Manufacturing Firms. The World Economy, 33(3), 399-423.

Girma, S., Görg, H., \& Stepanok, I. (2020). Subsidies, spillovers and exports. Economics Letters, 186, 108840.

Gnizy, I., Cadogan, J. W., Oliveira, J. S., \& Nizam, A. (2017). The empirical link between export dispersion and export performance: A contingency-based approach. International Business Review, 26(2), 239-249.

Grossman, G. M., \& Helpman, E. (1994). Endogenous Innovation in the Theory of Growth. Journal of Economic Perspectives, 8(1), 23-44.

Hu, C., \& Tan, Y. (2016). Export spillovers and export performance in China. China Economic Review, 41, 75-89.

Huberman, G., \& Kahn, C. (1988). Limited Contract Enforcement and Strategic Renegotiation. American Economic Review, 78(3), 471-484.

Krugman, P. (1991). Increasing Returns and Economic Geography. Journal of Political Economy, 99(3), $483-499$.

Krugman, P. (1999). Balance Sheets, the Transfer Problem, and Financial Crises. International Tax and Public Finance, 6(4), 459-472.

Legislation Information System, 36245 (1990). https://www.mevzuat.gov.tr/aramasonuc

Lindman, H. R. (1974). Analysis of variance in complex experimental designs (1st edition). W. H. Freeman.

O'Rourke, K. H. (2001). Globalization and Inequality: Historical Trends. National Bureau of Economic Research.

Sørensen, A. (2020). Export promotion and intra-industry reallocations. Review of International Economics, 28(2), 303-319.

Srhoj, S., \& Walde, J. (2020). Getting ready for EU Single Market: The effect of export-oriented grant schemes on firm performance. Structural Change and Economic Dynamics, 52, 279-293.

Stigler, G. (1971). The Theory of Economic Regulation. Bell Journal of Economics, 2(1), 3-21.

Student. (1908). The Probable Error of a Mean. Biometrika, 6(1), 1-25.

Zhang, K. H., \& Song, S. (2001). Promoting exports: The role of inward FDI in China. China Economic Review, 11(4), 385-396. 


\section{DOPRINOS ORGANIZACIJE ZA RAZVOJ MSP IZVOZU: PRIMER IZ REGIONA}

U ovom radu, proučavani su efekti subvencija agencije KOSGEB (Organizacija za razvoj MSP u Turskoj) na izvozne aktivnosti MSP i naglašene su aktivnosti koje bi KOSGEB trebalo da preduzme. Korišćeni su T test, ANOVA test i TUKEY test, a istraživanje je sprovedeno u Gazijantepu, šestom po veličini gradu u Turskoj. Prema rezultatima, problemi kompanija su pristup tržištima, finansijski problemi, kvalifikovano osoblje, jezici, $i$ visoki troškovi za kadrove, sirovine i proizvodnju. Za rešavanje ovih problema, KOSGEB treba da sprovede aktivnosti kao što su istraživanje tržišta, pronalazak mušterija, pružanje finsnijske podrške, doprinos platama kvalifikovanog osoblja, podrška aktivnostima istraživanja i razvoja i pružanje konsultatntskih usluga.

Ključne reči: Grant, Trgovina, Izvoz, MSP 